\title{
PERUBAHAN SIFAT FISIKOKIMIA SELAMA PENGOLAHAN BAWANG PUTIH TUNGGAL MENJADI BAWANG HITAM MENGGUNAKAN RICE COOKER
}

\section{THE PHYSICO-CHEMICAL PROPERTIES CHANGING DURING SINGLE CLOVES GARLIC PROCESSING INTO BLACK GARLIC USING RICE COOKER}

\author{
Illah Sailah*) dan Maulana Miladulhaq \\ Departemen Teknologi Industri Pertanian, Fakultas Teknologi Pertanian, Institut Pertanian Bogor \\ Kampus IPB Dramaga, Bogor 16680, Indonesia \\ Email: illahsailah@apps.ipb.ac.id,maulana.miladulhaq96@gmail.com \\ Makalah: Diterima 22 Januaril 2020; Diperbaiki 31 Maret 2021; Disetujui 20 April 2021
}

\begin{abstract}
Black garlic is a fermented product of single bulb garlic, and has been studied to have many health benefits, as it contains allicin agent. At present it is not known exactly how long it takes to process single bulb garlic into black garlic by a simple method with characteristics similar to commercial black garlic. The objectives of this research were to study the characteristics of black garlic during the fermentation process and to determine the optimum duration on fermentation. This research was carried out through several stages including pre-study, characterization of raw materials, producing of black garlic, and observation on the physical and chemical contents of black garlic. Characterization of physical and chemical contents during processing consisted of water content, colour, reducing sugar, volatile compound, and amino acid content. The results of black garlic characterization showed a decrease in moisture content by $0.92 \%$ every three days. The result of measurement of brightness level $\left(L^{*}\right)$ on the $3^{\text {rd }}$ to $18^{\text {th }}$ day decreased from $72.59 \%$ to $37.07 \%$. The reducing sugar content increased during the heating process until day $15^{\text {th }}(29.17 \%)$. While the volatile compound decreased from 43.27 $\mu_{e q} / g$ to $6.99 \mu_{e q} / g$ on the $18^{\text {th }}$ day. The best duration of processing was 15 days, and generally, amino acid content remained the same between fresh garlic and black garlic.
\end{abstract}

Keywords: black garlic, characteristics of black garlic, single bulb garlic,

\section{ABSTRAK}

Bawang hitam merupakan produk fermentasi dari bawang putih tunggal yang telah banyak dipelajari memberikan manfaat untuk kesehatan, karena mengandung senyawa allisin. Saat ini tidak diketahui lama pengolahan bawang putih tunggal menjadi bawang hitam dengan metode yang sederhana dan karakteristik yang mendekati bawang hitam komersial. Sehubungan dengan itu, tujuan penelitian ini adalah untuk mengetahui perubahan sifat fisiko kimia selama proses fermentasi, dan menentukan lama pengolahan menjadi bawang hitam. Penelitian dilakukan melalui beberapa tahapan, yaitu prapenelitian, karakterisasi bahan baku, proses pembuatan bawang hitam, dan karakterisasi bawang hitam. Karakterisasi fisik dan kimia bawang hitam selama proses pemanasan meliputi pengujian kadar air, warna, gula pereduksi (metode DNS), senyawa volatil (metode VRS), dan kandungan asam amino. Hasil karakterisasi bawang hitam menunjukkan penurunan kadar air sebesar $0,92 \%$ setiap tiga hari. Hasil pengukuran tingkat kecerahan $\left(\mathrm{L}^{*}\right)$ pada hari ke-3 hingga ke-18 mengalami penurunan dari $72,59 \%$ menjadi $37,07 \%$. Kandungan gula pereduksi mengalami peningkatan selama proses pemanasan sampai hari ke-15 (29,17\%). Senyawa volatil mengalami penurunan dari 43,27 $\mu \mathrm{eq} / \mathrm{g}$ menjadi $6,99 \mu \mathrm{eq} / \mathrm{g}$ pada hari ke-18. Lama pemanasan yang baik adalah 15 hari dan secara umum kandungan asam amino bawang putih sama dengan bawang hitam.

Kata kunci: bawang putih tunggal, bawang hitam, karakteristik bawang hitam

\section{PENDAHULUAN}

Masyarakat dunia pada saat ini lebih cenderung untuk hidup dengan konsep kembali ke alam (back to nature). Salah satu bahan alami yang memiliki banyak manfaat adalah bawang putih Tunggal. Menurut Untari (2010), bawang putih tunggal merupakan bawang putih yang hanya memiliki satu siung. Bawang putih biasa yang tumbuh di lingkungan yang tidak sesuai menyebabkan bawang putih tunggal tidak berkembang dengan baik dan hanya memiliki satu siung. Ba wang putih tunggal memiliki kandungan senyawa S-alil-L-sistein 5-6 kali lebih tinggi dibandingkan bawang putih biasa sehingga bawang putih tunggal lebih sering digunakan sebagai obat herbal (Bae et al.,2012).

Bawang putih memiliki banyak manfaat bagi kesehatan, namun konsumsi bawang putih mentah terbatas. Hal tersebut disebabkan karena bawang putih mentah memiliki aroma dan rasa yang menyengat karena mengandung senyawa organosulfur, sehingga membuat beberapa orang tidak nyaman. Li et al. (2014) menyatakan bahwa 
terdapat berbagai metode pengolahan bawang putih mentah, seperti fermentasi dan pemanasan dalam waktu yang lama untuk menghilangkan bau yang menyengat, memberikan cita rasa manis, dan meningkatkan efek menguntungkan bagi kesehatan manusia. Salah satunya adalah bawang hitam yang merupakan produk olahan bawang putih, yang diperoleh dengan menjaga bawang putih segar pada suhu tinggi serta kelembaban terkontrol selama 60-90 hari tanpa bahan tambahan lain (Bae et al., 2012), dan dapat menghilangkan aroma organosulfur.

Saat ini sudah banyak masyarakat yang mengolah bawang putih tunggal menjadi bawang hitam menggunakan rice cooker, namun belum terdapat penelitian lebih lanjut mengenai karakteristik bawang hitam yang dihasilkan. Pada penelitian ini dilakukan karakterisasi bawang hitam yang diproses menggunakan rice cooker.

\section{BAHAN DAN METODE}

\section{Bahan}

Bahan yang digunakan disediakan untuk setiap tahap. Tahap pemanasan terdiri dari bawang putih tunggal, aluminium foil, kertas tisu, dan air. Bahan yang digunakan pada tahap pengujian terdiri atas bawang hitam, bawang hitam komersial, asam borat $\left(\mathrm{H}_{3} \mathrm{BO}_{3}\right)$, asam sulfat $\left(\mathrm{H}_{2} \mathrm{SO}_{4}\right)$, natrium hidroksida $(\mathrm{NaOH})$, tembaga (II) sulfat $\left(\mathrm{CuSO}_{4}\right)$, sodium sulfat $\left(\mathrm{Na}_{2} \mathrm{SO}_{4}\right)$, natrium tiosulfat $\left(\mathrm{Na}_{2} \mathrm{~S}_{2} \mathrm{O}_{3}\right)$, kalium iododa (KI), kalium permanganate $\left(\mathrm{KMnO}_{4}\right)$, indikator kanji, indikator mansel, reagen DNS, dan akuades.

\section{Metode Pengolahan}

Proses pembuatan bawang hitam diawali dengan menimbang bawang putih tunggal seberat 100 gram. Kemudian, setiap $100 \mathrm{~g}$ bawang putih tunggal dibungkus menggunakan kertas tisu dan aluminium foil, lalu dimasukkan ke dalam rice cooker (warm mode) pada suhu $\pm 60-70^{\circ} \mathrm{C}$ dan $\mathrm{Rh} \pm 60-80 \%$ selama 18 hari. Bahan yang dimasukkan ke dalam rice cooker sebanyak 10x100 g. Kemudian dilakukan analisa bawang hitam setiap tiga hari.

\section{Uji Kadar Warna}

Uji kadar warna dilakukan setiap 3 hari selama proses pengolahan bawang hitam. Pengujian warna dilakukan secara objektif menggunakan alat Colorimeter Hunter. Menurut Indiarto et al. (2012), sistem notasi warna Colorimeter Hunter dicirikan dengan tiga parameter $\mathrm{L}^{*}$, $\mathrm{a}^{*}$, dan $\mathrm{b}^{*}$ (CIE L*a*b). Nilai L* antara 0-100 dari warna hitam hingga putih. Makin tinggi nilai $\mathrm{L}^{*}$ maka makin tinggi derajat keputihannya. Nilai a* dan $b^{*}$ antara nilai positif dan negatif. Untuk $a^{*}$ menunjukkan derajat hijau $\left(a^{*}-\right)$ hingga merah $\left(\mathrm{a}^{*+}\right)$, sedangkan $\mathrm{b}^{*}$ menunjukkan derajat kuning $\left(b^{*+}\right)$ hingga biru $\left(b^{*}-\right)$.

\section{Uji Kadar Air}

Sebanyak satu g contoh dikeringkan di dalam oven pada suhu $100^{\circ} \mathrm{C}$ selama 4 jam. Selanjutnya didinginkan dalam desikator dan ditimbang sampai diperoleh bobot yang tetap.

$$
\text { Kadar air }(\%)=\frac{(a-b)}{a} \times 100 \%
$$

Dimana :

$\mathrm{a}=$ Bobot awal

$\mathrm{b}=$ Bobot akhir

\section{Uji Kadar Gula Pereduksi}

Setiap sampel diambil sebanyak $1 \mathrm{~g}$ dan diencerkan sebanyak $100 \mathrm{~mL}$. Hasil pengenceran sampel diambil sebanyak $1 \mathrm{~mL}$ dan dimasikkan ke dalam tabung reaksi. Lalu sampel tersebut ditambahkan $3 \mathrm{ml}$ pereaksi DNS dan dipanaskan dalam air mendidih tepat 5 menit pada suhu $100^{\circ} \mathrm{C}$. Kemudian didinginkan dengan air mengalir dan diukur absorbansinya pada panjang gelombang 540 nm.

\section{Uji Kadar Senyawa Volatil (Farber dan Ferro, 1956)}

Sebanyak 5 g sampel dimasukkan ke dalam alat VRS dan ditambahkan $10 \mathrm{~mL}$ akuades. $\begin{array}{lllllll}\text { Kemudian sebanyak } & 10 & \mathrm{~mL} & \mathrm{KMnO}_{4} & 0,02 & \mathrm{~N}\end{array}$ dimasukkan ke dalam gelas reaksi pada alat VRS dan dilakukan aerasi dengan pompa vakum selama 40 menit. Setelah aerasi dilakukan, $\mathrm{KMnO}_{4}$ dipindahkan ke dalam Erlenmeyer dan ditambahkan $5 \mathrm{~mL} \mathrm{H}_{2} \mathrm{SO}_{4}$ $6 \mathrm{~N}$ sambil dibilas. Lalu ditambahkan $3 \mathrm{~mL}$ KI 20\% dan indikator kanji 1\%. Kemudian dititrasi dengan $\mathrm{Na}_{2} \mathrm{~S}_{2} \mathrm{O}_{3} \quad 0,02 \mathrm{~N}$ sampai warna biru hilang. Rumus yang digunakan yaitu:

$$
V R S=\frac{(b l-c) \times N \times 1000}{b}
$$

Keterangan:

$\begin{array}{ll}\text { VRS } & \text { : Volatile Reducing Substance }(\mu \mathrm{eq} / \mathrm{g}) \\ \text { bl } & \text { : Jumlah larutan } \mathrm{Na}_{2} \mathrm{~S}_{2} \mathrm{O}_{3} \text { titrasi blanko }(\mathrm{ml}) \\ \text { c } & \text { : Jumlah larutan } \mathrm{Na}_{2} \mathrm{~S}_{2} \mathrm{O}_{3} \text { titrasi sampel }(\mathrm{ml}) \\ \text { b } & \text { : Berat sampel }(\text { gram }) \\ \mathrm{N} & \text { : Normalitas larutan } \mathrm{Na}_{2} \mathrm{~S}_{2} \mathrm{O}_{3}\end{array}$

\section{Uji Asam Amino dan Nitrogen}

Sebanyak $5 \mathrm{~g}$ sampel bawang hitam dipotong, digiling dan dipindahkan ke labu volumetrik $100 \mathrm{~mL}$ dengan air suling. Larutan diekstraksi dengan menggunakan ultrasound selama 30 menit, dibiarkan sesaat, lalu disaring. Sebanyak 20 $\mathrm{mL}$ filtrat dilarutkan dalam $60 \mathrm{~mL}$ air suling, dan dimasukkan ke dalam gelas kimia. Elektroda dari $\mathrm{pH}$ meter dimasukkan ke dalam campuran, yang diaduk menggunakan pengaduk magnet. Kemudian larutan tersebut dititrasi dengan $0,05 \mathrm{~mol} \mathrm{~L}^{-1} \mathrm{NaOH}$ hingga $\mathrm{pH}$ 8,2. Jumlah larutan $\mathrm{NaOH}$ yang dikonsumsi dicatat. Kemudian $10 \mathrm{~mL}$ formaldehida ditambahkan ke dalam campuran. Larutan $\mathrm{NaOH}\left(0,05 \mathrm{~mol} \mathrm{~L}^{-1}\right)$ digunakan untuk mentitrasi campuran hingga $\mathrm{pH} 9.2$. Jumlah larutan $\mathrm{NaOH}$ yang dikonsumsi dicatat. 
Kemudian dilakukan perlakuan yang sama dengan menggunakan $80 \mathrm{~mL}$ air suling sebagai blanko. Jumlah larutan $\mathrm{NaOH}$ yang dikonsumsi digunakan untuk menghitung kandungan asam amino nitrogen dan kandungan total asam (Zhang et al., 2015).

\section{Uji Total Fenol}

Penentuan total fenol dapat dilakukan dengan metode Folin-Ciocalteu. Prinsip metode FolinCiocalteu adalah reaksi oksidasi dan reduksi kolorimetrik untuk mengukur semua senyawa fenolik dalam sampel uji. Kurva standar asam galat dibuat dengan variasi konsentrasi 0,$4 ; 0,8 ; 1,2 ; 1,6 ; 2,0$; dan $2,4 \mathrm{mg} / \mathrm{L}$ dan diukur absorbansinya pada $765 \mathrm{~nm}$. Prosedur pengukuran sampel dilakukan dengan cara memasukkan $0,4 \mathrm{~mL}$ sampel dan $0,4 \mathrm{~mL}$ reagen Folin-Ciocalteu ke dalam labu takar $10 \mathrm{~mL}$. Campuran kemudian dikocok selama lima menit. Setelah itu tambahkan $4 \mathrm{~mL} \mathrm{Na2CO} 37 \%$, tepatkan dengan akuades sampai volume $10 \mathrm{~mL}$. Larutan diinkubasi selama 40 menit pada suhu $23^{\circ} \mathrm{C}$ dan dibaca absorbansinya pada $\lambda=765 \mathrm{~nm}$ menggunakan spektrofotometer (Hammerschmidt dan Prett, 1978). Kadar total fenol diperoleh menggunakan rumus berikut:

$$
\text { Kadar Total Fenol }=\frac{C x V \times f p x f k}{\text { gram ekstrak }}
$$

Keterangan:

$\mathrm{C}=$ konsentrasi ekivalen dari grafik (nilai $\mathrm{x}$ )

$\mathrm{V}=$ volume yang diukur pada spektronik

$\mathrm{fp}=$ faktor pengenceran

$\mathrm{fk}=$ faktor konversi

\section{HASIL DAN PEMBAHASAN}

\section{Karakteristik Bahan Baku}

Karakterisasi merupakan suatu kegiatan yang dilakukan untuk mengetahui ciri spesifik yang dimiliki oleh suatu obyek penelitian. Karakterisasi bahan baku meliputi karakterisasi fisik dan kimia. Karakterisasi fisik meliputi ukuran dan warna. Paramater ukuran bawang putih tunggal adalah bobot, diameter, dan tinggi. Sedangkan parameter pada uji warna adalah nilai L*, a*, dan b*. Karakterisasi kimia meliputi kadar air, kadar abu, kadar protein, kadar karbohidrat, kadar gula pereduksi, dan kadar senyawa volatil.

Bawang putih tunggal yang digunakan memiliki bobot rata-rata $2,45 \mathrm{~g}$ dengan rentang bobot antara 1,85-3,59 g. Diameter bawang putih tunggal yang digunakan berkisar antara 1,31-1,89 cm dengan rata-rata $1,64 \mathrm{~cm}$, sedangkan, tinggi bawang putih tunggal yang digunakan berkisar antara 1,49-2,79 cm dengan rata-rata $2,01 \mathrm{~cm}$.

Hasil uji warna menunjukkan nilai kecerahan (L*) yang cukup tinggi, yaitu sebesar 72,59. Nilai a* pada bahan baku sebesar 12,65. Nilai tersebut menunjukkan bahwa bahan baku memiliki derajat warna merah yang rendah. Sedangkan nilai b* sebesar
13,96 yang menunjukkan bahwa bahan baku memiliki derajat warna biru yang rendah pula. Karakterisasi fisik bawang putih tunggal secara keseluruhan tersaji pada Tabel 1 .

Tabel 1. Hasil karakterisasi fisik bawang putih tunggal

\begin{tabular}{lccc}
\hline \multicolumn{2}{l}{ Parameter Uji } & Satuan & Hasil \\
\hline Bobot & & gram & $2,45 \pm 0,54$ \\
Diameter & & $\mathrm{cm}$ & $1,64 \pm 0,19$ \\
Tinggi & & $\mathrm{cm}$ & $2,01 \pm 0,44$ \\
Warna & $\mathrm{L}^{*}$ & & 71,59 \\
& $\mathrm{a}^{*}$ & & 12,65 \\
& $\mathrm{~b}^{*}$ & & 13,96 \\
\hline
\end{tabular}

Kandungan senyawa volatil yang terdapat dalam bawang putih tunggal cukup tinggi, yaitu sebesar $43,27 \mu_{\mathrm{eq}} / \mathrm{g}$. Senyawa volatil yang terdapat pada bawang putih tunggal didominasi oleh senyawa organosulfur. Martinez (2007) menyatakan bahwa senyawa organosulfur sangat bermanfaat dalam pengobatan. Menurut Amigase (2006), senyawa organosulfur yang paling banyak terdapat dalam bawang putih adalah alliin. Senyawa alliin bertanggung jawab pada bau dan rasa bawang putih. Senyawa alliin merupakan asam amino yang mengandung sulfur yang digunakan sebagai prekursor allisin. Allisin merupakan senyawa sulfur yang volatil dan kurang stabil akibat adanya pengaruh air panas, oksigen udara, dan lingkungan basa serta mudah sekali terdekomposisi menjadi senyawa sulfur yang lain seperti dialil sulfida (Ikhtiarsyah et al., 2014). Dialil sulfida dapat mencegah perkembangan penyakit kardiovaskular dengan membantu detoksifikasi sel (Omar et al., 2007). Karakterisasi kimia bawang putih tunggal secara keseluruhan tersaji pada Tabel 2 .

Tabel 2. Hasil karakterisasi kimia bawang putih tunggal

\begin{tabular}{lcc}
\hline Parameter Uji & Satuan & Hasil \\
\hline Kadar air & $\% \mathrm{~b} / \mathrm{b}$ & 58,84 \\
Kadar abu & $\% \mathrm{~b} / \mathrm{b}$ & 1,05 \\
Kadar protein & $\% \mathrm{~b} / \mathrm{b}$ & 6,22 \\
Kadar gula total & $\% \mathrm{~b} / \mathrm{b}$ & 37,51 \\
Kadar gula pereduksi & $\% \mathrm{~b} / \mathrm{b}$ & 0 \\
Kadar senyawa volatil & $\mu_{\mathrm{eq}} / \mathrm{g}$ & 43,27 \\
\hline
\end{tabular}

\section{Karakteristik Bawang Hitam}

Karakterisasi yang dilakukan terhadap bawang hitam meliputi uji warna, kadar air, kadar gula pereduksi, dan kandungan senyawa volatil. Bawang hitam yang diproses akan diuji setiap 3 hari, lalu dibandingkan dengan bawang hitam komersial hingga karakteristiknya mendekati bawang hitam komersial.

\section{Perubahan Fisik}

Bawang putih tunggal yang dipanaskan dengan menggunakan rice cooker mengalami 
perubahan fisik berupa perubahan tekstur dan warna. Bawang putih tunggal segar memiliki teskstur yang lebih keras dibandingkan bawang hitam. Selama proses pemanasan, tekstur bawang putih tunggal menjadi lebih lunak. Hal ini disebabkan karena pemanasan dengan suhu dan Rh tinggi menyebabkan tekstur bawang putih tunggal menjadi lebih lunak, akibat dari ikatan serat terurai menjadi gula sederhana. Bawang hitam yang dihasilkan memiliki tekstur yang sama dengan bawang hitam acuan.

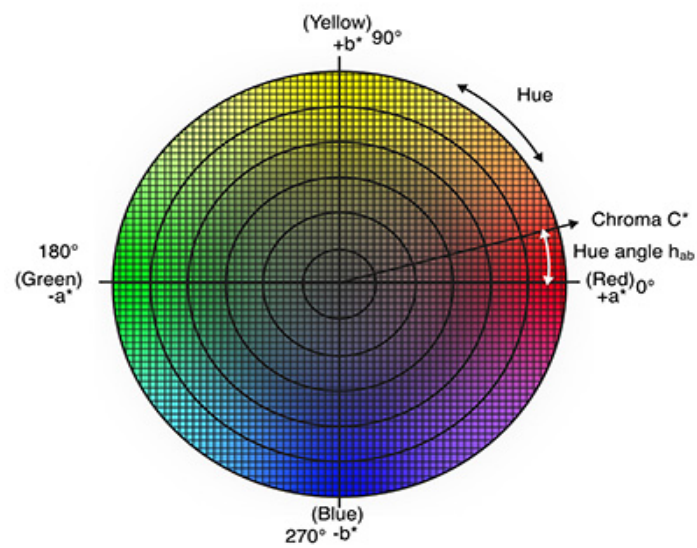

Gambar 1. Diagram warna CIE L*a*b*

Warna bawang putih tunggal juga mengalami perubahan selama proses pemanasan. Warna merupakan suatu sifat bahan yang berasal dari penyebaran spektrum sinar. Pengujian warna dilakukan secara objektif menggunakan alat Colorimeter Hunter. Menurut Indiarto et al. (2012), sistem notasi warna Colorimeter Hunter dicirikan dengan tiga parameter $\mathrm{L}^{*}, \mathrm{a}^{*}$, dan $\mathrm{b}^{*}($ CIE L*a*b). Nilai L* antara 0-100 dari warna hitam hingga putih. Makin tinggi nilai $\mathrm{L}^{*}$ maka makin tinggi derajat keputihannya. Nilai a* dan $b^{*}$ antara nilai positif dan negatif. Untuk $a^{*}$ menunjukkan derajat hijau $\left(a^{*}-\right)$ hingga merah $\left(\mathrm{a}^{*+}\right)$, sedangkan $\mathrm{b}^{*}$ menunjukkan derajat kuning $\left(b^{*+}\right)$ hingga biru $\left(b^{*}-\right)$. Gambar 1 menunjukkan diagram warna CIE $\mathrm{L}^{*} \mathrm{a}{ }^{*} \mathrm{~b}^{*}$ yang digunakan untuk mengekspresikan warna objek menggunakan beberapa jenis notasi angka.

Gambar 2 menunjukkan bahwa semakin lama proses pemanasan maka warna bawang menjadi semakin gelap. Hal tersebut disebabkan karena penurunan nilai $L^{*}, a^{*}$, dan $b^{*}$. Nilai $L^{*}, a^{*}$, dan $b^{*}$ secara rinci dapat dilihat pada Tabel 2 . Nilai $\mathrm{L}^{*}$ yang semakin rendah menunjukkan bahwa bawang putih tunggal memiliki warna yang semakin gelap. Nilai $\mathrm{a}^{*+}$ dan $\mathrm{b}^{*+}$ yang semakin mendekati nol menunjukkan bahwa tingkat warna merah dan kuning semakin berkurang selama proses pemanasan bawang putih tunggal. Berkurangnya komponen warna terang seperti merah dan kuning menunjukkan bahwa warna bawang menjadi semakin hitam. Perubahan warna pada bawang putih tunggal disebabkan karena terjadi reaksi Maillard. Reaksi Maillard merupakan reaksi utama antara gula pereduksi dengan komponen amino yang meningkat kecepatannya seiring dengan meningkatnya suhu dan menurunnya kadar air (Mottram, 1991). Reaksi maillard menimbulkan warna kecoklatan pada bawang. Semakin lama proses pemanasan, maka warna coklat akibat reaksi maillard akan semakin pekat sehingga bawang terkesan berwarna hitam. Perubahan warna bawang putih tunggal selama proses pemanasan dapat dilihat pada Gambar 3.

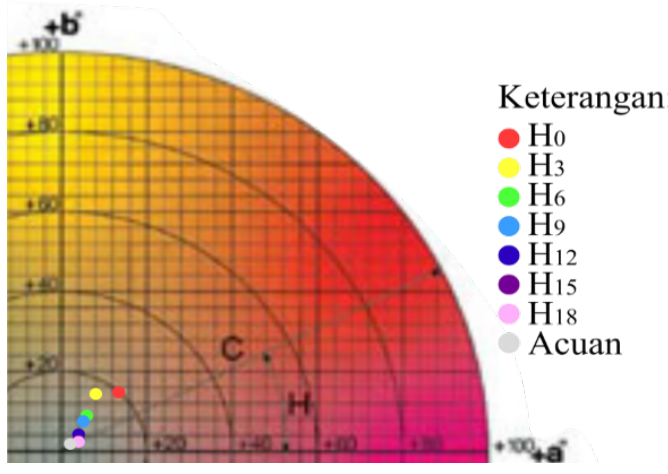

Gambar 2. Diagram warna CIE L*a*b* bawang putih tunggal selama proses pemanasan

Tabel 3. Derajat warna bawang putih tunggal selama proses pemanasan

\begin{tabular}{cccc}
\hline Sampel & $\mathbf{L}^{*}$ & $\mathbf{a}^{*}$ & $\mathbf{b}^{*}$ \\
\hline Acuan & 40,45 & 2,99 & 0,96 \\
$\mathrm{H}_{0}$ & 72,59 & 12,65 & 13,96 \\
$\mathrm{H}_{3}$ & 47,76 & 8,17 & 13,07 \\
$\mathrm{H}_{6}$ & 43,68 & 6,95 & 8,65 \\
$\mathrm{H}_{9}$ & 41,79 & 5,16 & 6,86 \\
$\mathrm{H}_{12}$ & 40,22 & 3,98 & 3,91 \\
$\mathrm{H}_{15}$ & 38,79 & 3,87 & 1,39 \\
$\mathrm{H}_{18}$ & 37,07 & 3,44 & 1,24 \\
\hline
\end{tabular}

\section{Perubahan Kimia \\ Kadar Air}

Menurut Aditya et al. (2016), air merupakan komponen penting dalam bahan pangan, karena dapat mempengaruhi penampilan, kesegaran, tekstur serta cita rasa pangan. Uji kadar air bertujuan untuk menunjukkan banyaknya air yang terkandung di dalam bahan. Kadar air bawang putih tunggal selama proses pemanasan dapat dilihat pada Gambar 4.

Gambar 4 menunjukkan bahwa terjadi penurunan kadar air bawang selama proses pemanasan menggunakan rice cooker, karena air dalam bahan menguap. Kadar air bawang putih tunggal pada hari ke-0 sebesar 58,84\%. Kadar air bawang putih tunggal setelah pemanasan selama 18 hari mengalami penurunan sampai pada angka kadar air 52,90\%. Rata-rata penurunan kadar air bawang putih tunggal per tiga hari sebesar $0,92 \%$. Pemanasan bawang putih tunggal dihentikan setelah 18 hari. 


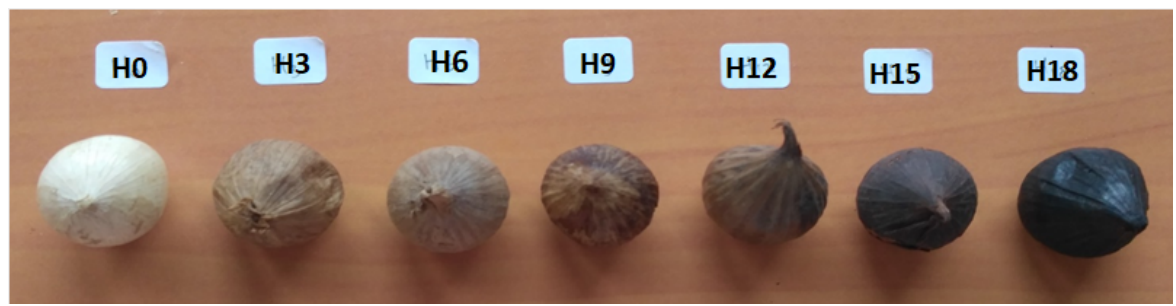

(a)

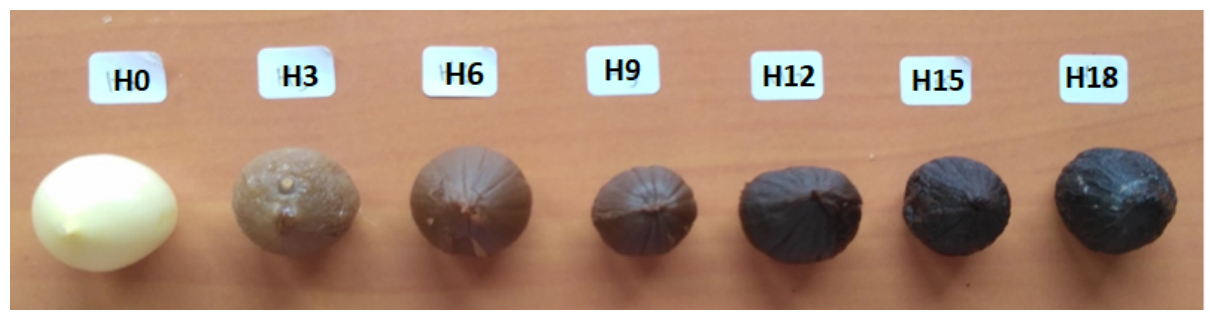

(b)

Gambar 3. Perubahan warna bawang putih tunggal selama proses pemanasan: (a) tampak luar (b) tampak dalam

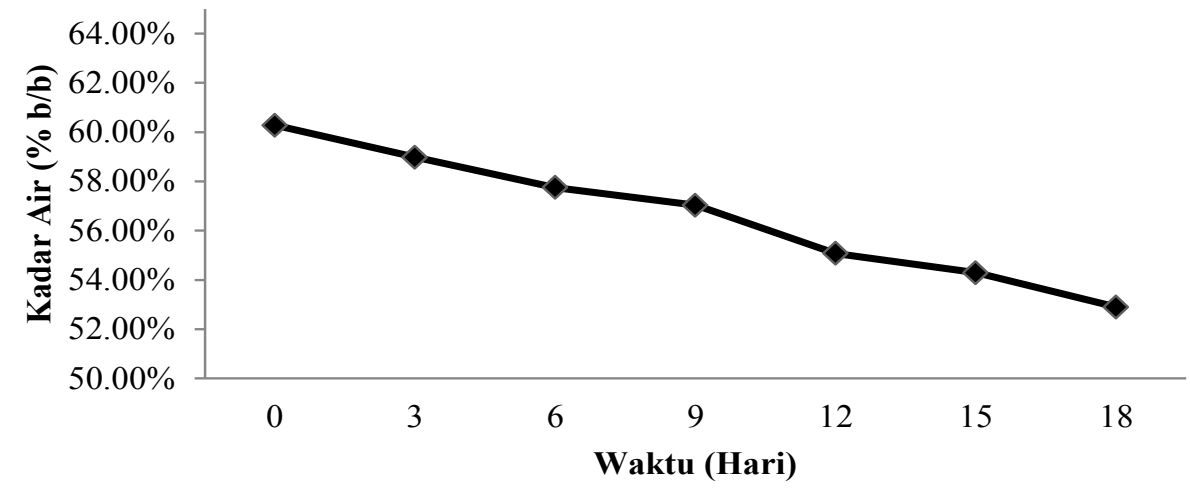

Gambar 4. Perubahan kadar air bawang putih tunggal selama proses pemanasan

Hal ini karena kadar air pada hari ke-18 berada dibawah kadar air bawang hitam acuan yang bernilai 53,08\%. Data perubahan kadar air selama proses pemanasan dapat dilihat pada Tabel 4.

Tabel 4. Perubahan kadar air bawang putih tunggal selama pemanas

\begin{tabular}{cc}
\hline Sampel & Kadar Air $(\mathbf{\% b} \mathbf{b})$ \\
\hline $\mathrm{H}_{0}$ & 58.84 \\
$\mathrm{H}_{3}$ & 58.31 \\
$\mathrm{H}_{6}$ & 58.27 \\
$\mathrm{H}_{9}$ & 57.49 \\
$\mathrm{H}_{12}$ & 54.87 \\
$\mathrm{H}_{15}$ & 53.60 \\
$\mathrm{H}_{18}$ & 52.90 \\
\hline
\end{tabular}

\section{Kadar Gula Pereduksi}

Menurut Sastrohamidjojo (2005), gula pereduksi adalah semua gula yang memiliki kemampuan untuk mereduksi dikarenakan adanya gugus aldehid atau keton bebas. Metode penentuan komposisi gula reduksi dalam sampel yang mengandung karbohidrat yang digunakan adalah menggunakan pereaksi asam dinitro salisilat (DNS) atau 3,5-dinitrosalicylic acid. Reaksi dengan DNS yang terjadi merupakan reaksi redoks pada gugus aldehid gula dan teroksidasi menjadi gugus karboksil. Sementara itu DNS sebagai oksidator akan tereduksi membentuk 3-amino dan 5-nitrosalicylic acid. Reaksi ini berjalan dalam suasana basa. Bila terdapat gula reduksi pada sampel, maka larutan DNS yang awalnya berwarna kuning akan berubah warna menjadi jingga kemerahan.

Gambar 5 menunjukkan bahwa terjadi peningkatan kadar gula pereduksi bawang selama proses pemanasan menggunakan rice cooker. Bawang putih tunggal pada hari ke-0 tidak mengandung gula pereduksi. Setelah dilakukan proses pemanasan terjadi peningkatan kadar gula pereduksi pada bawang putih tunggal. Hasil penelitian menunjukkan bahwa kadar gula pereduksi bawang putih tunggal selama proses pemanasan mengalami peningkatan sampai hari ke-15 dan mengalami penuruanan pada hari ke-18. 


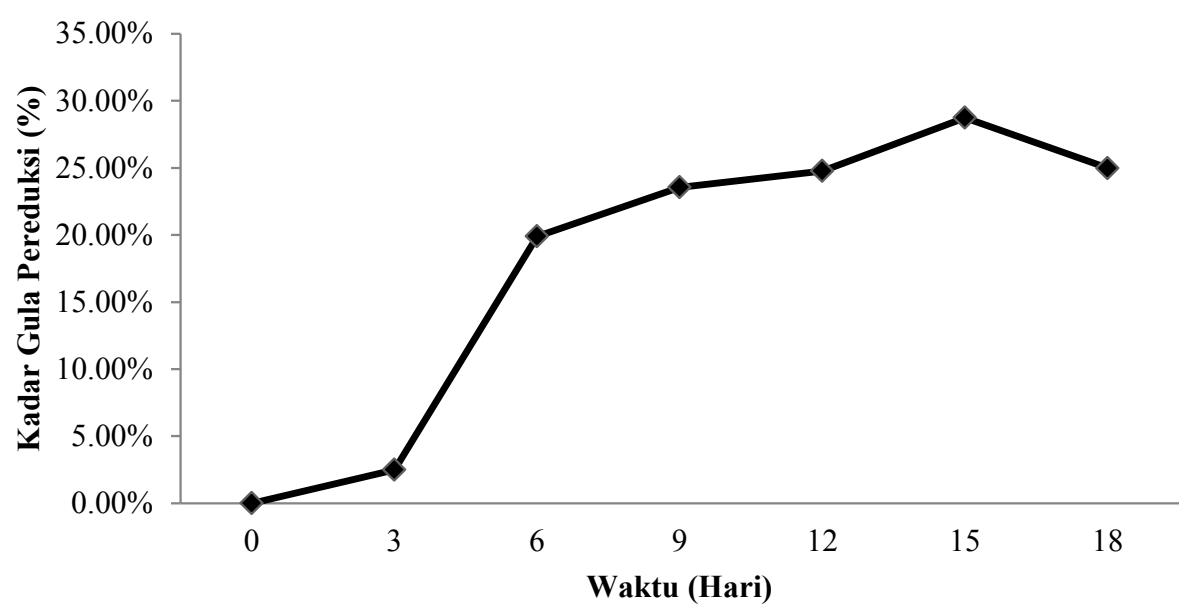

Gambar 5. Perubahan kadar gula pereduksi bawang putih tunggal selama proses pemanasan

Menurut Zhang et al. (2014), terdapat dua faktor yang mempengaruhi kandungan gula pereduksi pada proses pembuatan bawang hitam. Di satu sisi, reaksi hidrolisis polisakarida menjadi gula pereduksi akan menyebabkan kadar gula pereduksi meningkat, sedangkan di sisi lain, terjadi reaksi Maillard yang menyebabkan penurunan kadar gula pereduksi. Peningkatan kadar gula pereduksi sampai hari ke-15 disebabkan karena reaksi hidrolisis polisakarida berlangsung lebih cepat dibandingkan reaksi Maillard. Setelah 15 hari, jumlah polisakarida yang direaksikan semakin berkurang sehingga menyebabkan laju reaksi hidrolisis lebih lambat dibandingkan reaksi Maillard. Hal ini yang menyebabkan terjadinya penurunan kadar gula pereduksi pada hari ke-18.

Tabel 5. Perubahan kadar gula pereduksi bawang putih tunggal selama pemanasan

\begin{tabular}{lcc}
\hline Sampel & Satuan & $\begin{array}{c}\text { Kadar Gula } \\
\text { Pereduksi }\end{array}$ \\
\hline $\mathrm{H}_{0}$ & $\%(\mathrm{~b} / \mathrm{b})$ & 0,00 \\
$\mathrm{H}_{3}$ & $\%(\mathrm{~b} / \mathrm{b})$ & 2,49 \\
$\mathrm{H}_{6}$ & $\%(\mathrm{~b} / \mathrm{b})$ & 19,89 \\
$\mathrm{H}_{9}$ & $\%(\mathrm{~b} / \mathrm{b})$ & 23,55 \\
$\mathrm{H}_{12}$ & $\%(\mathrm{~b} / \mathrm{b})$ & 24,77 \\
$\mathrm{H}_{15}$ & $\%(\mathrm{~b} / \mathrm{b})$ & 29,17 \\
$\mathrm{H}_{18}$ & $\%(\mathrm{~b} / \mathrm{b})$ & 25,83 \\
\hline
\end{tabular}

Tabel 5 menunjukkan bahwa kadar gula pereduksi bawang hitam pada hari ke-15 telah mendekati bawang hitam komersial. Hal ini dapat ditunjukkan dari data kadar gula pereduksi bawang hitam pada hari ke-15 yang mencapai 29,17\%, sedangkan bawang hitam komersial memiliki kadar gula pereduksi sebesar 30,87\%.

\section{Uji Senyawa Volatil}

Mutia et al. (2014) menyatakan bahwa Volatile Reducing Substance (VRS) merupakan zat-zat yang mudah menguap dalam suatu bahan atau produk dan memberikan aroma yang khas pada famili bawangbawangan. Semakin tinggi kadar VRS pada suatu bahan menunjukkan aroma yang semakin tajam. Pengujian kadar VRS bertujuan untuk mengetahui seberapa besar kandungan senyawa-senyawa volatil pada bahan (Sudibyo et al., 2010).

Gambar 6 menunjukkan bahwa terjadi penurunan kadar VRS bawang putih tunggal selama proses pemanasan menggunakan rice cooker. Astuti (2009) menyatakan bahwa pengeringan yang lama memacu penguapan senyawa volatil sehingga kadarnya pada bahan kering menjadi rendah. Selain itu, kadar VRS mudah menguap pada suhu tinggi dan sensitif terhadap panas sehingga semakin lama proses pemanasan, kadar VRS bahan akan berkurang. Sampai saat ini belum ada informasi apabila VRS menurun akan menurunkan khasiat bawang hitam sebagai obat herbal. Namun dengan menurunnya bilangan VRS pada bawang hitam akan disukai oleh konsumen yang tidak suka aroma menyengat pada bawang putih. Kadar VRS bawang putih tunggal pada hari ke-0 sebesar 43,27 $\mu_{\text {eq }} / \mathrm{g}$. Kadar VRS bawang putih tunggal setelah pemanasan mengalami penurunan. Kadar VRS pada 3 hari pertama sebesar $37,61 \mu \mathrm{eq} / \mathrm{g}$ terus menurun hingga menjadi $6,99 \mu_{\mathrm{eq}} / \mathrm{g}$ pada hari ke-18. Hasil penelitian menunjukkan bahwa kadar VRS bawang pada hari ke-9 telah lebih rendah dengan produk acuan yang memiliki kadar VRS sebesar 20,87 $\mu_{\mathrm{eq}} / \mathrm{g}$. Penurunan kadar VRS dapat dilihat pada Tabel 6 .

\section{Penentuan Waktu Proses Terbaik}

Hasil karakterisasi bawang hitam kemudian dianalisa dengan ANOVA $(\alpha=0,05)$ dan uji lanjut Duncan. Hasil ANOVA $(\alpha=0,05)$ menunjukkan bahwa lama waktu pemanasan berpengaruh terhadap tingkat kecerahan warna, kadar air, kadar gula pereduksi, dan kadar VRS bawang hitam yang dihasilkan. Hasil uji lanjut Duncan $(\alpha=0,05)$ menunjukkan bahwa tingkat kecerahan warna bawang hitam tidak berbeda nyata dengan bawang hitam komersial pada hari ke-6 hingga 12 . 


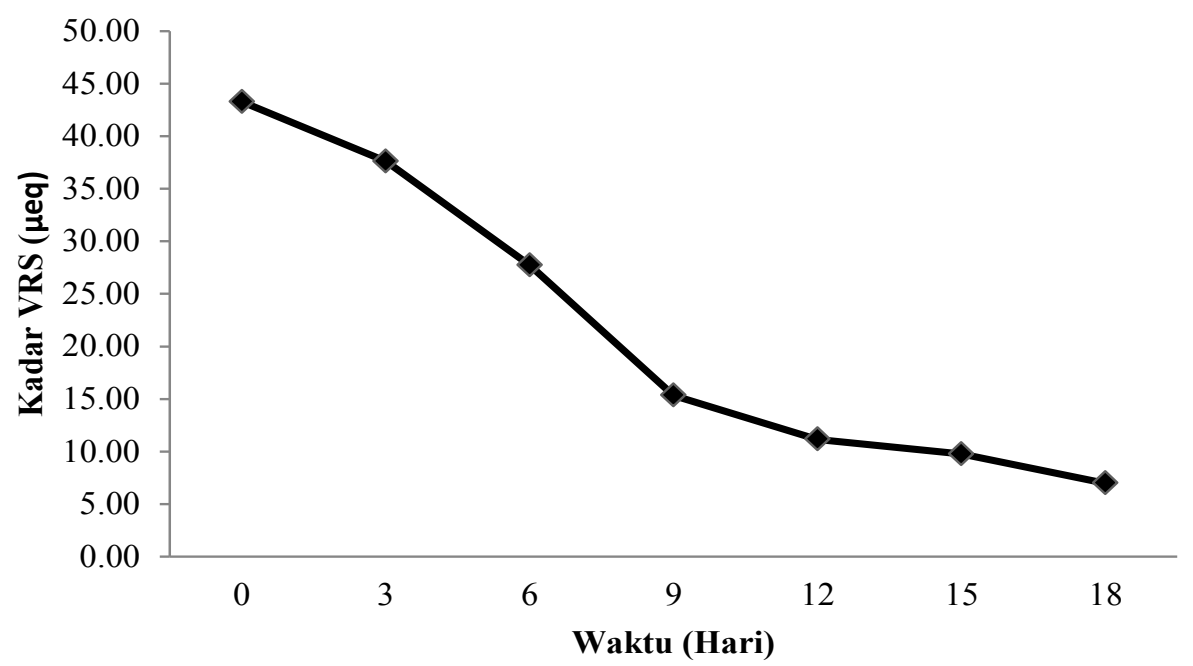

Gambar 6. Perubahan kadar VRS bawang putih tunggal selama proses pemanasan

Hal ini menunjukkan bahwa pada hari ke-6 hingga 12, warna bawang hitam sesuai dengan bawang hitam komersial. Hasil uji lanjut Duncan $(\alpha=0,05)$ menunjukkan bahwa kadar air bawang hitam tidak berbeda nyata dengan bawang hitam komersial pada hari ke-15 dan 18. Hal ini menunjukkan bahwa pada hari ke-15 dan 18 kadar air bawang hitam sesuai dengan bawang hitam komersial, sedangkan kadar gula pereduksi bawang hitam berbeda nyata dengan bawang hitam komersial pada hari ke-0 hingga 18 . Hal ini menunjukkan bahwa pada hari ke-0 hingga 18, kadar gula pereduksi bawang hitam tidak sesuai dengan bawang hitam komersial. Nilai kadar gula pereduksi yang paling mendekati bawang hitam komersial yaitu pada hari ke-15.

Tabel 6. Perubahan kadar VRS bawang putih tunggal selama pemanasan

\begin{tabular}{lcc}
\hline Sampel & Satuan & $\begin{array}{c}\text { Kadar Gula } \\
\text { Pereduksi }\end{array}$ \\
\hline $\mathrm{H}_{0}$ & $\mu_{\mathrm{eq}} / \mathrm{g}$ & 43,27 \\
$\mathrm{H}_{3}$ & $\mu_{\mathrm{eq}} / \mathrm{g}$ & 37,61 \\
$\mathrm{H}_{6}$ & $\mu_{\mathrm{eq}} / \mathrm{g}$ & 27,73 \\
$\mathrm{H}_{9}$ & $\mu_{\mathrm{eq}} / \mathrm{g}$ & 15,33 \\
$\mathrm{H}_{12}$ & $\mu_{\mathrm{eq}} / \mathrm{g}$ & 11,17 \\
$\mathrm{H}_{15}$ & $\mu_{\mathrm{eq}} / \mathrm{g}$ & 9,77 \\
$\mathrm{H}_{18}$ & $\mu_{\mathrm{eq}} / \mathrm{g}$ & 6,99 \\
\hline
\end{tabular}

Hasil uji lanjut Duncan $(\alpha=0,05)$ menunjukkan bahwa kadar VRS bawang hitam pada hari ke-0 hingga 18 berbeda nyata dengan bawang hitam komersial. Hal ini menunjukkan bahwa pada hari ke-0 hingga 18, kadar VRS bawang hitam tidak sesuai dengan bawang hitam komersial. Pada hari ke0 hingga ke-6, kadar VRS bawang hitam masih lebih tinggi dibandingkan bawang komersial. Pada hari ke9 hingga 18, kadar VRS bawang hitam lebih rendah dibandingkan bawang hitam komersial. Pada uji VRS dipilih bawang hitam pada hari ke-9 hingga 18 karena semakin rendah kadar VRS, aroma yang dihasilkan bawang hitam semakin berkurang.

Waktu proses pembuatan bawang hitam menggunakan rice cooker terbaik berdasarkan hasil uji lanjut Duncan terhadap parameter tingkat kecerahan warna, kadar air, kadar gula pereduksi, dan kadar VRS adalah pada hari ke-15. Meskipun memiliki tingkat kecerahan warna yang berbeda dibandingkan bawang hitam komersial, namun kadar air dan kadar gula pereduksi bawang hitam pada hari ke-15 mendekati bawang hitam komersial. Selain itu, bawang hitam pada hari ke-15 juga memiliki kadar VRS yang rendah.

\section{Karakteristik Lanjutan Bawang}

Hasil penelitian menunjukkan bahwa bawang hitam yang diproses menggunakan rice cooker memiliki karakteristik yang mendekati bawang hitam komersial pada hari ke-15. Perbandingan karakteristik bawang putih tunggal, bawang hitam komersial, dan bawang hitam pada hari ke-15 disajikan dalam Tabel 7.

Tabel 7 menunjukkan karakteristik bawang putih tunggal, bawang hitam komersial, dan bawang hitam yang diolah menggunakan rice cooker. Hasil uji warna menunjukkan bahwa derajat keputihan bawang hitam yang diproses menggunakan rice cooker lebih hitam dibandingkan bawang hitam komersial. Kadar air pada bawang hitam yang diolah dengan menggunakan rice cooker memiliki nilai yang sama dengan bawang hitam komersial.

Hasil penelitian menunjukkan bahwa bawang putih tunggal segar tidak mengandung gula pereduksi, sedangkan bawang hitam mengandung gula pereduksi yang cukup tinggi. Bawang hitam yang diolah dengan menggunakan rice cooker memiliki kandungan gula pereduksi sedikit lebih rendah dibandingkan bawang hitam komersial. 
Tabel 7. Perbandingan karakteristik bawang

\begin{tabular}{lcccc}
\hline Parameter Uji & Satuan & $\begin{array}{c}\text { Bawang putih } \\
\text { tunggal }\end{array}$ & $\begin{array}{c}\text { Bawang hitam } \\
\text { komersial }\end{array}$ & $\begin{array}{c}\text { Bawang hitam pada } \\
\text { hari ke-15 (Rice } \\
\text { Cooker) }\end{array}$ \\
\hline Warna & $\%(\mathrm{~b} / \mathrm{b})$ & 67,69 & 40,45 & 30,62 \\
Kadar air & 60,27 & 53,08 & 53,60 \\
Kadar gula pereduksi & $\%(\mathrm{~b} / \mathrm{b})$ & 0 & 30,87 & 28,74 \\
Kadar VRS & $\mu \mathrm{eq} / \mathrm{g}$ & 43,27 & 20,87 & 9,77 \\
Kadar nitrogen & $\%(\mathrm{~b} / \mathrm{b})$ & 0,94 & 0,53 & 0,62 \\
Total fenol & $\%(\mathrm{~b} / \mathrm{b})$ & 0,99 & 0,38 & 0,69 \\
Asam amino & $\%(\mathrm{~b} / \mathrm{b})$ & 3,46 & 2,50 & 2,38 \\
\hline
\end{tabular}

Tingginya kadar gula pereduksi menyebabkan bawang hitam memiliki rasa yang lebih manis dibandingkan bawang putih tunggal segar. Bawang putih tunggal memiliki kandungan senyawa volatil tertinggi, yaitu sebesar 43,27 $\mu \mathrm{eq} / \mathrm{g}$. Sedangkan bawang hitam yang diolah menggunakan rice cooker memiliki kadar senyawa volatil terendah, yaitu sebesar 9,77 $\mu_{\text {eq }} / \mathrm{g}$ pada hari ke-15. Hal ini menunjukkan bahwa bawang hitam yang diolah dengan menggunakan rice cooker tidak memiliki aroma yang menyengat.

Li et al. (2014), menyatakan bahwa nitrogen dan asam amino merupakan bahan yang penting pada reaksi Maillard dan kandungannya berpengaruh langsung terhadap kualitas bawang hitam. Hasil uji kadar nitrogen menunjukkan bahwa terjadi penurunan kadar nitrogen bawang hitam dibandingkan bawang putih tunggal. Hasil ini telah sesuai dengan penelitian $\mathrm{Li}$ et al. (2014) yang menyatakan bahwa kadar nitrogen berkurang selama proses pemanasan. Kadar nitrogen pada bawang hitam lebih kecil dibandingkan bawang putih segar. Kandungan nitrogen bawang hitam hasil pemanasan menggunakan rice cooker lebih tinggi dibandingkan bawang hitam komersial. Hal ini menunjukkan bahwa kualitas bawang hitam yang dopanaskan dengan menggunakan rice cooker lebih baik dibandingkan bawang hitam komersial.

Li et al. (2014) menyatakan bahwa senyawa fenolik menunjukkan sifat antibakteri, antitumor, dan antioksidan yang berperan penting dalam bawang hitam. Hasil penelitian menunjukkan bahwa kandungan total fenol bawang putih tunggal lebih tinggi dibandingkan bawang hitam maupun bawang hitam komersial. Namun kandungan total fenol bawang hitam masih lebih tinggi dibandingkan bawang hitam komersial. Hasil ini tidak sesuai dengan hasil penelitian $\mathrm{Li}$ et al. (2014) yang menyatakan bahwa kandungan total fenol bawang hitam meningkat dibandingkan bawang putih segar. Penurunan total fenol diduga disebabkan karena larutnya fenol dalam air pada saat penambahan air. Selama proses pemanasan dilakukan penambahan air untuk menjaga $\mathrm{Rh}$ supaya tetap konstan pada kisaran 60-80\%. Lund (1977) menyatakan bahwa selama proses pemanasan dinding sel dan membran plasma cepat mengalami kerusakan. Dengan demikian, penambahan air saat proses pemanasan menyebabkan air masuk ke dalam dinding sel dan vakuola yang kemudian melarutkan senyawa fenol ke dasar rice cooker. Hal ini didukung dengan adanya kerak berwarna hitam pada dasar rice cooker yang ditunjukkan pada Gambar 7.

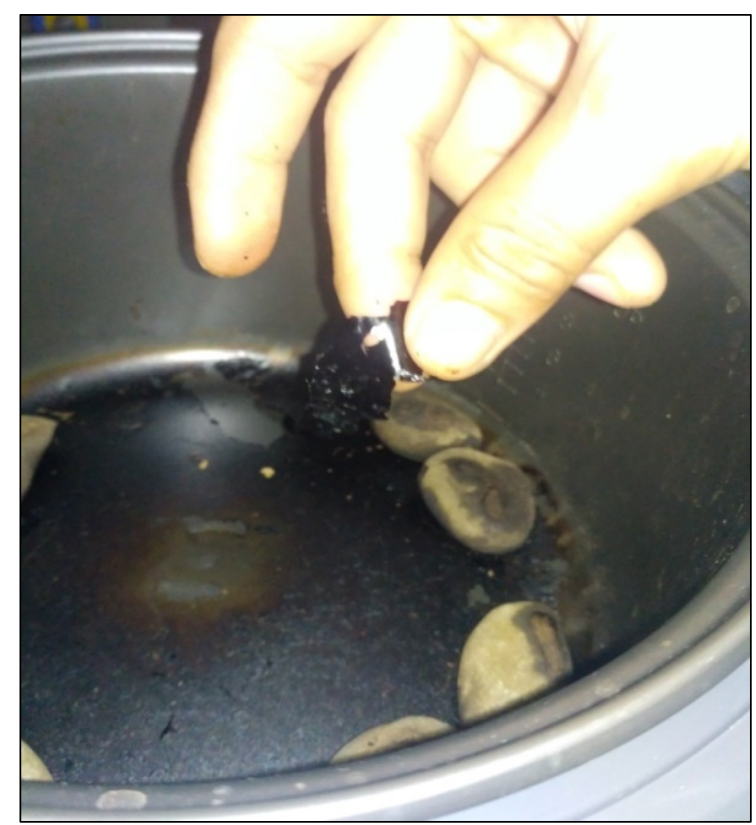

Gambar 7. Kerak hitam pada dasar rice cooker

\section{Uji Kandungan Asam Amino}

Winarono (2004) menyatakan bahwa asam amino merupakan substansi dasar penyusun protein dan bisa diproduksi sendiri oleh tubuh untuk keperluan metabolism. Asam amino ditemukan pada semua makanan yang mengandung protein. Kurniawati dan Istiningrum (2018) menyatakan bahwa terdapat lebih dari 300 jenis asam amino yang ada di alam, namun hanya 20 jenis asam amino yang menyusun protein. Manusia dan hewan tingkat tinggi hanya bisa mensintesis 10 dari 20 jenis asam amino tersebut sehingga membutuhkan tambahan nutrisi yang mengandung asam amino dari sumber makanannya. Jenis asam amino penyusun protein yaitu glisin, alanin, prolin, valin, leusin, isoleusin, metionin, fenilalanin, tirosin, triptofan, serin, treonin, sistein, aspargin, glutamin, lisin, histidin, arginin, 
asam aspartat, dan asam glutamat. Hasil uji kandungan asam amino menunjukkan bahwa bawang putih tunggal mengandung 15 dari 20 jenis asam amino penyusun protein. Terdapat 5 jenis asam amino yang tidak terdapat dalam bawang hitam, yaitu prolin, triptofan, sistein, aspargin, dan glutamin. Perbandingan kandungan asam amino pada bawang putih tunggal tersaji pada Tabel 8 .

Hasil penelitian menunjukkan terjadi penurunan kadar asam amino bawang putih tunggal setelah diproses menjadi bawang hitam. Hal ini disebabkan karena terjadi reaksi Maillard selama proses pemanasan bawang. Mottram (1991) menyatakan bahwa peningkatan suhu dan penurunan kadar air menyebabkan gula pereduksi berikatan komponen amino pada bahan, sehingga kandungan asam amino bawang menurun.

Berdasarkan Tabel 8, asam amino yang dominan pada bawang putih tunggal adalah arginin dengan kadar tertinggi sebesar $1,11 \%$. Rasullah et al. (2013) mengungkapkan bahwa arginin merupakan jenis asam amino semi esensial yang dapat dibentuk oleh tubuh dalam jumlah terbatas, sehingga masih perlu penambahan dari luar. Arginin dapat diperoleh dengan mengonsumsi makanan yang bersumber dari hewan, seperti daging, telur, dan susu. Kandungan arginin pada bawang hitam berkurang menjadi $0,39 \%$ setelah dilakukan proses pemanasan. Hal ini disebabkan karena arginin ikut bereaksi dengan gula pereduksi saat terjadi reaksi Maillard sehingga kandungannya berkurang.

Asam amino yang tidak mengalami perubahan selama proses pengolahan yaitu leusin dan I-leusin. Kandungan leusin dan I-leusin masingmasing sebesar 0,17 dan $0,12 \%(b / b)$. Doi et al. (2005) menyatakan bahwa isoleusin dan leusin mampu merangsang penyerapan glukosa dalam selsel otot sehingga dapat menurunkan kandungan gula dalam darah. Hal ini menunjukkan bahwa bawang putih tunggal segar maupun olahan (bawang hitam) memiliki kemampuan untuk menurunkan gula darah yang sama. Namun bawang hitam memiliki aroma dan rasa yang lebih baik daripada bawang putih tunggal segar.

\section{KESIMPULAN DAN SARAN}

\section{Kesimpulan}

Bawang putih tunggal yang dipanaskan dengan menggunakan rice cooker mengalami perubahan fisik berupa perubahan tekstur menjadi lebih lunak dan warna menjadi hitam. Selama proses pemanasan juga terjadi perubahan kimia, yaitu perubahan kadar air, kadar gula pereduksi, dan kadar VRS. Bawang putih tunggal mengalami penurunan kadar air dan kadar VRS masing-masing sebesar $0,92 \%$ dan $6,05 \mu$ eq $/$ g per tiga hari selama 18 hari. Sedangkan kadar gula pereduksi mengalami peningkatan mencapai $29,17 \%$ pada hari ke-15 dan kembali berkurang pada hari ke18.

Waktu optimal proses pemanasan bawang putih tunggal menjadi bawang hitam menggunakan rice cooker agar sesuai dengan produk acuan adalah 15 hari. Bawang hitam hasil pemanasan menggunakan rice cooker selama 15 hari telah memiliki nilai kadar air, kadar gula pereduksi, kadar VRS, dan derajat warna yang mendekati bawang hitam komersial.

\section{Saran}

Penelitian ini belum membahas mengenai kandungan S-Alil-L-Sistein, aktivitas superoksida dismutase (SOD), aktivitas antioksidan, dan scavenging activity melawan hidrogen peroksida pada bawang hitam yang diolah menggunakan rice cooker. Selain itu, pengemasan dan umur simpan produk bawang hitam yang dihasilkan juga belum dibahas, sehinggga diperlukan penelitian lebih lanjut mengenai hal tersebut

Tabel 8. Perbandingan kandungan asam amino bawang

\begin{tabular}{lcccc}
\hline Asam Amino & Satuan & $\begin{array}{c}\text { Bawang putih } \\
\text { tunggal }\end{array}$ & $\begin{array}{c}\text { Bawang Hitam } \\
\text { Komersial }\end{array}$ & Bawang Hitam \\
\hline Apartic acid & $\%(\mathrm{~b} / \mathrm{b})$ & 0,35 & 0,30 & 0,30 \\
Glutamic Acid & $\%(\mathrm{~b} / \mathrm{b})$ & 0,55 & 0,58 & 0,46 \\
Serine & $\%(\mathrm{~b} / \mathrm{b})$ & 0,14 & 0,14 & 0,12 \\
Histidine & $\%(\mathrm{~b} / \mathrm{b})$ & 0,10 & 0,07 & 0,06 \\
Glycine & $\%(\mathrm{~b} / \mathrm{b})$ & 0,13 & 0,11 & 0,10 \\
Threonine & $\%(\mathrm{~b} / \mathrm{b})$ & 0,10 & 0,08 & 0,07 \\
Arginine & $\%(\mathrm{~b} / \mathrm{b})$ & 1,11 & 0,31 & 0,39 \\
Alanine & $\%(\mathrm{~b} / \mathrm{b})$ & 0,14 & 0,13 & 0,12 \\
Tyrosine & $\%(\mathrm{~b} / \mathrm{b})$ & 0,15 & 0,12 & 0,11 \\
Methionine & $\%(\mathrm{~b} / \mathrm{b})$ & 0,03 & 0,05 & 0,16 \\
Valine & $\%(\mathrm{~b} / \mathrm{b})$ & 0,16 & 0,15 & 0,10 \\
Phenylalanine & $\%(\mathrm{~b} / \mathrm{b})$ & 0,13 & 0,12 & 0,12 \\
I-leucine & $\%(\mathrm{~b} / \mathrm{b})$ & 0,12 & 0,12 & 0,17 \\
Leucine & $\%(\mathrm{~b} / \mathrm{b})$ & 0,17 & 0,17 & 0,06 \\
Lysine & $\%(\mathrm{~b} / \mathrm{b})$ & 0,08 & 0,04 & 2,38 \\
\hline Total & $\%(\mathrm{~b} / \mathrm{b})$ & 3,46 & 2,50 & \\
\hline
\end{tabular}




\section{DAFTAR PUSTAKA}

Aditya HP, Herpandi, dan Lestari S. 2016. Karakteristik fisik, kimia dan sensoris abon ikan dari berbagai ikan ekonomis rendah. Jurnal Teknologi Hasil Perikanan. 5(1): 61-72

Astuti SM. 2009. Teknik pengaturan suhu dan waktu pengeringan beku bawang daun (Allium fistulosum L.). Buletin Teknik Pertanian. 14(1):17-22

Bae SE, Cho SY, Won YD, Lee SH, Park HJ. 2012. A comparative study of the different analytical methods for analysis of S-allyl cysteine in black garlic by HPLC. LWT-Food Science and Technology. 46:532-535

Doi M, Yamaoka I, Nakayama M, Mochizuki S, Sugahara K, Yoshizawa F. 2005. Isoleucine, a blood glucose-lowering amino acid, increase glucose uptake in rat skeletal muscle in the absence of increases in AMP-activated protein kinase activity. Journal Nutr. 135(9):21032108

Ikhtiarsyah YG, Armandaria I, Supriati MD, Sulistyorini E. 2014. Bawang Putih (Allium sativum L.) [internet]. [diunduh 2018 Jul 25]. Tersedia pada: https://ccrc.farmasi.ugm.ac.id/?page id=441

Indiarto R, Nurhadi B, dan Subroto E. 2012. Kajian karakteristik tekstur (texture profil analysis) dan organoleptik daging ayam asap berbasis teknologi asap cair tempurung kelapa. Jurnal Teknologi Hasil Pertanian. 5:106-116

Kurniawati P dan Istiningrum RB. 2018. Modul Biokimia Jilid 1. Yogyakarta : Universitas Islam Indonesia

Lestari S. 2013. Profil pertumbuhan dan analisis kandungan karbohidrat, protein, dan lipid mikroalga hijau-biru pada medium af-6 dengan penambahan substrat limbah ampas sagu. [Skripsi]. Bandung (ID): Universitas Pendidikan Indonesia

Lee YM, Gweon OC, Seo YJ, Im J, Kang MJ. Kim MJ, Kim JI. 200). Antioxidant effect of garlic and aged black garlic in animal model of type 2 diabetes mellitus. Nutr. Res. Pract. 3(2):156-161. https://doi.org/10.4162/nrp.2009.3.2.156
Lund, D.B. 1977. Effect of Heating Processing on Nutrients. Westport : The AVI Publishing Company

Li N, Lu X, Pei H, Qiao X. 2014. Effect of freezing pretreatment on the processing time and quality of black garlic. Journal of Food Process Engineering. 38:329-335

Mutia AK, Purwanto YA, dan Pujantoro L. 2014. Perubahan kualitas bawang merah (Allium ascalonicum L.) selama penyimpanan pada tingkat kadar air dan suhu yang berbeda. Jurnal Pascapanen. 11(2):108-115

Omar SH, Hasan A, Hunjul N, Ali J, Aqil M. 2007. Historical, chemical and cardiovascular perspectives on garlic: A review. Phcog Rev [Internet]. [Diunduh 2018 Jul 25]; 1(1):80-87 Tersedia pada: http://www.phcogrev.com/article.asp?issn=09 73-7847; year $=2007$;

volume $=1 ;$ issue $=1 ;$ spage $=80 ;$ epage $=8$

7 ; aulast $=$ Omar;type $=0$

Rasullah FFF, T Nurhidayati, dan Nurmalasari. 2013. Respon pertumbuhan tunas kultur meristem apikal tanaman tebu (Saccharum officinarum) varietas nxi 1-3 secara in viro pada media ms dengan penambahan arginin dan glutamin. Sains dan Seni Pomits. 2(1):2337-3520

Sastrohamidjojo H. 2005. Kimia Organik, Sterokimia, Lemak, dan Protein. Yogyakarta: Gadjah Mada University Press.

Shang A, Cao, S. Y., Xu, X. Y., Gan, R. Y., Tang, G. Y., Corke, H., Mavumengwana, V., \& Li, H. B. (2019). Bioactive Compounds and Biological Functions of Garlic (Allium sativum L.). Foods (Basel, Switzerland), 8(7): 246.

Sudibyo A, Hutajulu TF, dan Setyadjit. 2010. Pendugaan masa simpan produk kopi instan menggunakan studi penyimpanan yang di akselerasi dengan model kinetika Arrhenius. Warta IHP. 27(1):12-24.

Untari I. 2010. Bawang putih sebagai obat paling mujarab bagi kesehatan. Gaster. 7(1):547-554

Zhang X, Li N, Lu X, Liu P, Qiao X. 2016. Effects of temperature on the quality of black garlic. Journal Science Food Agricuture. 96:23662372 